\title{
Zakat Corporatism: The Way to Improve the Management of Zakat Institutions in Indonesia
}

\author{
Lungid Wicaksana $^{1 *}$, Kristina Setyowati ${ }^{1}$, Didik Gunawan Suharto ${ }^{1}$
}

\author{
${ }^{1}$ Master of Public Administration, Universitas Sebelas Maret, Surakarta, Indonesia \\ *Corresponding author. Email: wlungid@gmail.com
}

\begin{abstract}
The emergence of a new law on the management of Zakat raises pros and cons, both among the citizen and private sector zakat institutions. What's more, recently, there were rules regarding payment of $2.5 \%$ zakat for Civil Servants. This seems to make the private sector zakat institution more subordinated. In several studies revealed that with the latest zakat management rules, private sector zakat institutions feel they don't get enough space and are subordinated to several existing policies. And it is feared that it will be very detrimental to the private sector zakat institution which is considered to have a small amount of people, because there must be a requirement that must be approved to obtain legality. Through a literature review study with Boolean Logic, several online journals were selected according to the needs of this study. The results show that corporatism in the management of zakat in Indonesia is the government's effort to increase the productivity of zakat, control and supervise the management of zakat by private institutions, and clarify the responsibilities between the government, the private sector, and the community in managing zakat. However, this raises perceptions of subordination, criminalization, restrictions on access, marginalization, centralization and discrimination. This has an impact on government interference in private areas which makes the country stronger and weakens the power of the people.
\end{abstract}

Keywords: corporatism, zakat, management

\section{INTRODUCTION}

Zakat law experts and Muslim economists predict that if zakat is managed properly and optimally, zakat will be one of the solutions to create prosperity for the community [1]. Because according to Didin Hafiduddin in [2] argues that one of the goals and benefits of zakat management is to help and foster the poor to a better and more prosperous life, so that they can meet their needs properly. From various existing studies, zakat becomes an alternative solution to the problem of poverty and social welfare, especially in countries with a Muslim majority in it such as in Indonesia. However, the problem that arises in collecting zakat funds such as in Indonesia is the large gap between the potential and the realization of the collection of existing zakat funds. Because of this gap, it causes a huge loss of wealth that can effectively be used to fight poverty [3]. And the fact is, not only in Indonesia, the gap between the potential and the realization of zakat collection occurs in several countries. [3] explains how the problem is a reflection of almost all Muslim-majority countries as happened in the state of Kano in Nigeria, where the population of 15 million people with 99 percent Muslims but the collection of zakat funds is fairly low. Whereas in Sudan, the collection of their zakat funds was relatively low before the issuance of a new policy in 1984 regarding the obligation of zakat [4]. According to Othman, Faridi, and Abdul [5], the low level of zakat collection in Malaysia, India, and Uganda has to do with ineffective communication between zakat administrators and zakat payers. When compared with GDP (Gross Domestic Product), zakat funds in some countries are also relatively low, which according to Kahf [5] estimates that the ratio of zakat income to national income (gross domestic product, or GDP) in the three countries that adopt the mandatory zakat system - Saudi Arabia, Yemen, and Pakistan - only between 0.3 and 0.4 percent of GDP

The problem of this potential gap needs to be given more attention from the government, because in Indonesia itself, with the majority of Muslims, especially in terms of collecting zakat funds is still not optimal. It is appropriate that Indonesia also implements programs that can boost the growth of zakat funds. Based on data in Indonesia, the gap in the collection of zakat funds is only compared to no more than $4 \%$ of the existing potential calculations, where in 2018 zakat was collected at IDR 8.1 trillion [6]. With the reference that the calculation of the potential is determined based on the calculation of the Indicator of Zakat Potential Mapping component, the zakat potential is IDR 233.8 trillion or equivalent to 1.72 percent of GDP (Gross Domestic Product) in 2017 [7]. And one of the possible reasons behind the poor performance of zakat collection in Muslim countries is related to the ineffectiveness of collection strategies implemented by zakat institutions [5]. Then, hot issues arise related to the collection of zakat. In order to reform the management of zakat which was previously considered not optimal, the government issued a new regulation on the management of zakat. The revision of Law No. 23 of 2011 concerning Management of Zakat with the aim of reforming zakat management strategies, obtaining pros and cons among existing Private Amil Zakat Institutions. They are of the opinion that the existence of the regulation is feared to make it difficult for small institutions 
with a small number of muzaki (citizens who required to pay zakat) to develop, even out of business. This is indicated by the demands of various Private Amil Zakat Institutions and the Zakat Society Coalition to the Constitutional Court to conduct a material review of the revision of the law. In their lawsuit, the petitioner considered the criminalization of Private Amil Zakat Institution and traditional zakat alms which did not have permission from the authorized officials and there were marginalization and restrictions on access to the distribution of zakat funds due to restrictions on Private Amil Zakat Institutions and amil zakat which were permitted to operate [8]. The petitioners considered the law was a form of centralization and discrimination against the existence of traditional amil zakat institutions [9]. Because in an article in the law states that the Amil Zakat Institution must be an official institution and authorized by the government. So according to Sabeth, Coordinator of the Zakat Society Coalition, as a result zakat that was previously collected through mosques and pesantren is no longer allowed when following Law No. 23 of 2011 [10]. Then, the assessment of problems in the management of zakat through this law, creates a question whether it will be able to have a positive impact on the synergy of zakat institutions and their effects on the management of zakat itself. Because it was allegedly, the management of zakat began to get the effect of government centralization through the patterns of state corporatism towards private zakat institutions in Indonesia. With the aim to find out whether through the corporatization of zakat is one of the appropriate alternative solutions in maximizing the function of the National Amil Zakat Agency as the only legal government-owned zakat organization that is expected to be able to optimize synergy between institutions and collection of zakat funds in Indonesia.

\section{METHOD}

Where this research uses the Boolean Logic method through online journal search based on the specifications of the main search operators such as AND, OR, NOT to narrow the journal search as needed by the author [11]. Through an online database search such as Scopus, Emerald Insight, Science Direct, Elsevier, and Google Scholar, a total of 18 online journals were found and selected according to the suitability of the study. Also, 4 online books and 2 online student theses were used as references in this study.

\section{RESULTS AND DISCUSSION}

\subsection{State Corporatism}

Basically, Corporatism is the idea of Phillips Schmitter, explained that the intention of corporatism is the process of efforts to connect the government with the community and society with the government [12]. Which can then be interpreted that the government began to open up to accept the changes that occur because it began to include the ideas of the private sector in the bureaucracy. However, according to Ismanto [13], corporateism is generally defined as a system of regulation adopted by the state towards the interests that develop in society. And MacIntyre explains that corporateism refers to the pattern of statesociety relations in which the state plays a major role in organizing and organizing interest groups, organizing them along functional lines rather than class lines (to minimize collaboration and conflict), and usually gives official recognition to only one representative bodies in any sector [13].

In its development in Indonesia, corporatism is a system that is applied to strengthen government control over labor affairs through certain coercion by the state [14]. Included in this category Fenwick [14] explains, that applied corporatism has (1) full control of workers' organizations, in terms of the recognition and registration of new members, which are directly handled by the government; (2) strong limits; (3) control over dispute resolution; (4) government monopoly over fund management. Then adopting from the ideas put forward by Schmitter, the dominant features of this state's corporatism are, (1) limited numbers; (2) single; (3) mandatory; (4) not competing with each other; (5) hierarchically arranged; (6) functional differentiation; (7) given a monopoly of representatives in their respective fields; (8) recognized and created by the state; (9) leadership selection and articulation of interests and support are controlled by the state [15]. So, Santoso [16] explained that there are several dimensions that need to be considered in studying a corporate system in a country, that is single, must have official permission, membership is mandatory, management must have permission from the government, the articulation of interests must be in accordance with the established framework the government, sources of authority from the government, financial resources from the government, as well as functions that must be carried out in order to maintain political stability, support the government and its policies, and submit proposals to the government. Even though in reality, the management of zakat raises new problems about Private Amil Zakat Institutions dissatisfaction which feels subordinated by the existing rules

\subsection{The Dynamics of Corporatism in the Management of Zakat}

In its journey, Law No. 23 of 2011 became an important study of zakat activists. Where it appears the assumption that as if making National Amil Zakat Agency as a central role by determining the various directions of zakat management policies such as there are certain targets that must be achieved, indicators determined by National Amil Zakat Agency, to obligations in reporting the management of zakat funds by Private Amil Zakat Institutions [17]. From the framework of this central role, National Amil Zakat Agency seems to subordinate Private Amil Zakat Institutions with several policies. If related to these regulations, the Private Amil Zakat Institutions subordination will increasingly be seen that the patterns of government corporatism towards the management of zakat are getting bigger. The existence of these regulations has an impact on the role played by Private Amil Zakat 
Institutions, namely as an operator and as if positioned as a subordinate, while other roles become the government's authority [18]. Zakat which was once considered a private domain, slowly began to be taken over by the government through National Amil Zakat Agency. In fact, the centralization of zakat management as part of government responsibility is also problematic because National Amil Zakat Agency still cannot perform well compared to privately managed institutions for various reasons [19].

Basically, in corporatism, the existence of a social organization is regulated, determined, even created by the government itself [20]. This opinion is supported by research [21] that in Sragen Regency, various Amil Zakat Institutions as an organization formed by the community must have a recommendation from National Amil Zakat Agency to be able to carry out all zakat management operations. Still in the study, Private Amil Zakat Institutions, which does not have a letter of recommendation from National Amil Zakat Agency, will be followed up by National Amil Zakat Agency. Through the assistance of the recommendation process up to the revocation of the zakat collection permit if in the end it is not able to meet the recommended requirements of National Amil Zakat Agency. Even in this case, the Minister of Religion can provide administrative sanctions for violations in the form of written warnings, suspension of operations to revocation of licenses [22]. And in the Constitutional Court Decision Number 86 / PUU-X / 2012, explained in the main petition, in essence that Law Number 23 of 2011 concerning Management of Zakat has an effect on the centralization, subordination and marginalization of Private Amil Zakat Institutions by National Amil Zakat Agency which is likely to potentially kill the Private Amil Zakat Institutions which totaled more than 300 throughout Indonesia in 2012. What's more, it was stated that there was a prohibition to act as amil (collector and distributor) of zakat without the permission of the authorities, which was the criminalization of Amil zakat which had no authorization even though they gained the trust of the community [19]. Adding to this, [8] revealed that the existence of the Act opened the opportunity for the state to be arbitrary by adding new conditions in establishing Private Amil Zakat Institutions. And more broadly, it can weaken the power of society and become a challenge in a democratic country (MacIntyre in [13]). Thus, the state becomes very strong in the eyes of society because the state organizes communities that have a variety of interests [23].

Other research shows that the government through National Amil Zakat Agency has a strong influence in the management of zakat in Indonesia. In research [24] shows that, (1) the existence of inequality between National Amil Zakat Agency and Private Amil Zakat Institutions; (2) Private Amil Zakat Institutions is required to report periodically regarding reporting on the collection, distribution, and utilization of the audited zakat to National Amil Zakat Agency; (3) strict requirements are applied in establishing Private Amil Zakat Institutions but not for National Amil Zakat Agency because of its status as a zakat management institution established by the government; (4) the establishment of National Amil Zakat Agency at all levels becomes the mandate of the law; (5) Law No. 23 of 2011 concerning zakat management, gives extraordinary privileges to National Amil Zakat Agency, thus creating a level of playing field that is not the same between National Amil Zakat Agency and Private Amil Zakat Institutions; (6) When Private Amil Zakat Institutions is faced with high performance discipline because its operational continuity is entirely dependent on zakat collected, National Amil Zakat Agency receives funding from the State Budget, Regional Budget, and still has the right to use zakat for its operations, namely amil rights. Where in fact, the private zakat sector is proven to be more active and creative in mobilizing zakat funds [24]. Taken from the Constitutional Court Decision Number 86 / PUU-X / 2012, the data shows that the average receipt of Zakat, Infaq, and Sodaqoh National Amil Zakat Agency between 2005 and 2007 was 32\% while Private Amil Zakat Institutions reached $68 \%$. In addition, the extraordinary privilege given to National Amil Zakat Agency raises the question of who has the right to audit Private Amil Zakat Institutions institutions, and who has the right to audit National Amil Zakat Agency [25]. Because in the establishment of National Amil Zakat Agency based on these regulations, without conditions according to the mandate of the law.

In addition, National Amil Zakat Agency's actions in directing 2.5\% salary cuts directly to National Amil Zakat Agency have another impact. Private Amil Zakat Institutions as a private sector is also undeniable that there are some of their people who become civil servants, so that the impact of collecting zakat by Private Amil Zakat Institutions will also be reduced. According to [21], this raises the problem of overlapping muzaki (zakat payers) which then has an impact on the seizure of zakat collection areas and fighting over muzaki. It was also seen that the National National Amil Zakat Agency increasingly moved quickly in developing Regional National Amil Zakat Agency which were deemed less effective. Shown through the National Amil Zakat Agency which was established from the central to the regency / city level where National Amil Zakat Agency at each level can form the Zakat Collecting Unit down to the kelurahan level [22]. In connection with the formation of National Amil Zakat Agency and Zakat Collecting Unit itself, in the regulation of zakat, both Law No. 23 of 2011 and Government Regulation of the Republic of Indonesia Number 14 of 2014, all matters relating to the existence of the National Amil Zakat Agency recruitment system, the government also participates in determining the appointment and dismissal of members up to members its leader. In fact, National Amil Zakat Agency can form Zakat Collecting Units at government agencies, state-owned enterprises, regionally-owned business entities, private companies, and representatives of the Republic of Indonesia abroad and can form Zakat Collecting Unit at the sub-district, sub-district or other names, and places the other. Where the formation, appointment, and dismissal of Zakat Collecting Unit members is determined by National Amil Zakat Agency and the government. This shows that the government began to enter the domains of community interests. This gave rise to the view that the government was beginning to limit the space for social organizations in the zakat sector.

It is feared that the regulation of zakat will lead to conflicts that were previously not expected, especially with the dualism of a religious organization that does have a fairly 
large community base. Moreover, there are still sentiments between religious organizations in Indonesia that cause the possibility of Private Amil Zakat Institutions affiliation to religious organizations not being optimal [18]. There are doubts that Private Amil Zakat Institutions is expected to be a part of community organizations (CSOs) that have not guaranteed its independence, so it is feared that in the form of CSOs there will be separation [26]. Zakat Forum Plenary Board considers that there are weaknesses in the law such as the unclear role of regulators, operators, coordinators and supervisors in the institutional arrangement of zakat which until now adds to the management dualism between Private Amil Zakat Institutions which belongs to the community and National Amil Zakat Agency which belongs to the government [25]. Also, a conflict of interest will emerge in relation to the recommendation for the establishment of Private Amil Zakat Institutions, because National Amil Zakat Agency as an operator with the same status as Private Amil Zakat Institutions has a motive of authority to tackle Private Amil Zakat Institutions establishment which has the potential to become its competitor [24].

However, the corporatism of zakat management, on the other hand, has indeed had a positive influence in the implementation of collection. Corporatization is actually a concrete step of an economic reform, which involves a process of institutional change that makes productivity increase [27]. One of them, disclosed by the Chairperson of the Central Java National Amil Zakat Agency, Kiai Haji Ahmad Darodji, thanks to the Circular Letter regarding the deduction of the Civil Servant salary by 2.5 each month with a total of around 42,679 people this has a significant impact on the collection of zakat in Central Java [28]. Even won the National Amil Zakat Agency Award as the National Amil Zakat Agency Province with the Best Collection of Zakat [29].

The pattern that emerged from the existence of pros and cons was indeed recognized as one of the ways applied to control and avoid conflicts of interest between religious groups in shading Private Amil Zakat Institutions. As stated, that corporatism aims to support its penetration into society, as well as in order to fully control the public [30]. On the other hand, to maximize effectiveness and efficiency, corporatization requires clear lines of relationship and responsibility between the parties involved and requires the formulation of clear objectives [27]. Because the control aspect becomes important for the continuity of the development of the community organization, where government control and intervention are generally exclusionary, that is, it does not recognize the existence of community organizations whose interests are considered to conflict or endanger the interests of the government [20]

\section{CONCLUSION}

Although basically there are still many pros and cons in the management of zakat over the emergence of the latest regulations in the management of zakat, the government itself has indeed thought about what is considered capable of having a positive impact in the management of zakat. One of them is marked by a significant increase in the collection of zakat funds from year to year. So it does not rule out the possibility that the patterns of corporatism that run in the management of zakat is one of the beginning of better management. Then, with the existence of this corporatism, the government is able to control and supervise the performance of private zakat institutions which are deemed unable to implement national zakat management programs. Also, clarify the relations, patterns, and responsibilities between the government, the private sector, and the community through a Memorandum of Understanding concerning the roles, programs and other agreed agreements. However, in its implementation, it gives rise to negative perceptions for Private Amil Zakat Institutions. They consider that this is a form of subordination, criminalization, restriction of access, marginalization, centralization, and discrimination. Where it has an impact on the start of government interference in the private area that makes the country stronger and weakens the power of society.

And as a recommendation in this study, to avoid any perceived subordination of Private Amil Zakat Institutions by National Amil Zakat Agency, it is necessary to apply Public Private Parnership. It was explained that in partnership involving the government, the private sector and the community without the nature of supervising each other with common goals based on the commitment to be achieved, having respective responsibilities in accordance with the agreement, as well as providing input both financially and non-financially to solve the limitations of each party without discrimination [31].

\section{ACKNOWLEDGMENT}

I am especially grateful for Dr Kristina Setyowati and Dr Didik G Suharto for the advice and support during the preparation of this article. And $i$ am deeply indebted for providing research fund assistance that helped in completing this research. Also, I am especially grateful to families who always give encouragement and always pray for the best for this research.

\section{REFERENCES}

[1] Asnaini, "Membangun Zakat Sebagai Upaya Membangun Masyarakat," La_Riba, vol. 4, no. 1, pp. 19-33, 2010.

[2] M. Azwar, “Zakat dan Kesejahteraan Sosial,” J. Islam., vol. V. No, 2, pp. 59-74, 2016.

[3] A. U. Farouk, K. Md Idris, and R. A. J. Bin Saad, "Moderating role of religiosity on Zakat compliance behavior in Nigeria," Int. J. Islam. Middle East. Financ. Manag., vol. 11, no. 3, pp. 357-373, 2018. 
[19] Saidurrahman, "The politics of zakat management in Indonesia: The tension between BAZ and LAZ," J. Indones. Islam, vol. 7, no. 2, pp. 366-382, 2013.

[20] Z. Nasution, "Bahasa sebagai Alat Komunikasi Politik dalam Rangka Mempertahankan Kekuasaan," Sodality J. Sosiol. Pedesaan, vol. 1, no. 3, pp. 445-464, 2007.

[21] L. Wicaksana, "Kemitraan Lembaga Pengelola Zakat Dalam Penghimpunan Zakat Di Kabupaten Sragen," Universitas Sebelas Maret, 2016.

[22] Asmawi and A. Faizin, "Kontekstualisasi Hukum Zakat Di Indonesia (Studi Tentang Legislasi Dan Konstitusionalitas UU Pengelolaan Zakat Dalam Perspektif Siyasah Syariyyah)," Istinbath J. Huk. Islam IAIN Mataram, vol. 16, no. 1, pp. 65-111, 2016.

[23] S. Anggara, Sistem Politik Indonesia. Bandung: CV Pustaka Setia, 2013.

[24] N. Fadhilah, "Oleh Masyarakat Dalam Peraturan Perundang-Undangan,” Yudisia, vol. 7, No. 2, pp. 498 533, 2016.

[25] Mufidah, "Sistem Hirarki Kelembagaan Badan Pengelola Zakat di Indonesia (Tinjauan Terhadap Pelaksanaan Undang-undang No. 23 Tahun 2011),” J. Cita Huk., vol. 4, no. 2, pp. 323-344, 2016.

[26] N. S. B. Utami. and D. B. Nugraheni, "Kriminalisasi Pengelolaan Zakat (Tinjauan Ketentuan Pasal 41 Uu No 23 Tahun 2011)," Yust. J. Huk., vol. 2, no. 1, pp. 46-56, 2013.

[27] E. S. Hamid, "Peran dan Intervensi Pemerintah dalam Perekonomian,” J. Emerg. Mark., vol. 4, no. 1, pp. 41-58, 1999.

[28] Setiawan, "Surat Ganjar Pranowo Bikin Zakat Di Jawa Tengah Tumbuh Tertinggi," 2019. [Online]. Available: www.bisnis.tempo.co. [Accessed: 25-Sep2019].

[29] Koran-Jakarta, "Inilah Pemenang Baznas Award 2019," 2019. [Online]. Available: www.koranjakarta.com.

[30] N. S. Yunas, “Kepemimpinan Dan Masa Depan Reformasi Birokrasi Di Indonesia," Dimensi, vol. 9, no. 2, pp. 103-114, 2016.

[31] D. Junus, "Kemitraan Pada Program Penanggulangan Kemiskinan Perkotaan,” J. Leg., vol. 3, no. 2, pp. 134-146, 2004.
[18] Ramadhita, "Optimalisasi Peran Lembaga Amil Zakat Dalam Kehidupan Sosial,” Jurisdictie, pp. 24-34, 2012. 